\title{
Managing Competency-Based Teaching of Teachers at Specialized High Schools in Hanoi
}

\author{
Nguyen Thi Nga \\ High School for Gifted Students, Hanoi National University of Education
}

\begin{abstract}
Managing competency-based teaching activities of teachers at specialized high schools includes 7 aspects: 1) Managing teaching goals; 2) Managing content of the teaching program; 3) Managing teaching methods; 4) Managing forms of teaching; 5) Managing educational facilities and equipment; 6) Managing the teaching environment; 7) Managing student assessment. A survey of 152 leaders and teachers at 3 specialized high schools in Hanoi on the management of competency-based teaching activities of teachers at specialized high schools showed that management of competency-based teaching activities was performed well and relatively even among 7 aspects.
\end{abstract}

KEYWORDS: Competency Approach; Management of Teaching Activity; Specialized High School; Teacher

\section{INTRODUCE}

Since 2010, The Ministry of Education and Training has determined to build and develop a system of High Schools for the Gifted becoming high-quality educational institutions, creating a source of talent training to meet the requirements of developing countries in the period of industrialization, modernization, and international integration (Government, 2010). To realize this goal, teachers at High schools for Gifted quickly applied teaching to develop students' ability to help students build their core and specialized competencies evenly. (Vuong, 2015). Teaching activities of teachers at the High schools for the Gifted are purposeful, oriented, and organized processes, in which the teacher acts as a guide for learners to be self-aware, active, and proactive. Creative in capturing knowledge, skills, and cultural values to effectively realize educational goals and develop learners' personalities.

For the teaching activities of teachers at High schools for the Gifted according to competence approach to perform effectively, to best meet the requirements and teaching tasks of teachers at high schools for the gifted according to competence approach, requires that the performance of the task of managing teaching activities of teachers at high schools needs to be focused on by the management subjects. In particular, attention to applying scientific management principles to the development of solutions to manage teaching activities of teachers at High schools for the Gifted according to the competency approach to suit the specific characteristics of these schools. Thereby, the effectiveness of teachers' teaching activities will improve.

Managing the teaching activities of teachers at gifted high schools according to the competency approach is the purposeful, oriented, and systematic influence of the management subject on the managed object. Therein, the teacher plays the role of a guide for students to be self-disciplined, active, proactive, and creative in acquiring knowledge, skills, and cultural values to realize educational goals, develop students' capacity effectively and the overall personality of learners.

Inheriting the views on the management and teaching activities in high schools of authors Bui Minh Hien, Nguyen Vu Bich Hien, Nguyen Xuan Thanh, Nguyen Quoc Tri, Do Van Dot, Vu Thi Mai Huong, Nguyen Thi Ngoc Lien, Nguyen Phuc Chau and some other authors, we define the content of managing teaching activities of teachers at gifted high schools according to competency approach as follows:1) Managing teaching objectives of the teacher; 2) Manage the implementation of the content of the teaching program; 3) Managing Innovation in the use of teaching methods; 4) Managing the proposal and selection of the form of teaching organization; 5 Management of educational facilities and equipment in the school; 6) Managing the teaching environment; 7) Management of assessment of teaching results.

This article focuses on clarifying the current situation of managing teaching activities of teachers at the gifted high schools in Hanoi according to the competency approach.

\section{RESEARCH ORGANIZATION AND METHODS}

\subsection{Research organization:}

The current situation survey was conducted at three gifted high schools in Hanoi city, including: 1) Hanoi - Amsterdam 


\section{International Journal of Current Science Research and Review}

ISSN: 2581-8341

Volume 04 Issue 10 October 2021

DOI: 10.47191/ijcsrr/V4-i10-03, Impact Factor: 5.825

IJCSRR @ 2021

www.ijesrr.org

High School for the Gifted. 2) High School for Foreign Languages, Foreign Language Specialized School, Vietnam National University, Hanoi. 3) High School for Gifted Students, Hanoi National University of Education.

Survey participants include administrators (school administrators, subject heads) and teachers at gifted high schools. The total number of survey subjects was 152 people, of which managers accounted for $13.2 \%$. Research sample $67.7 \%$ of participants have seniority over six years; $55.9 \%$ have a university degree, and $42.7 \%$ have a graduate degree (only $1.4 \%$ of teachers have a college degree).

\subsection{Methods:}

The research uses two main methods, questionnaire survey and mathematical statistics, to study the current situation of managing teaching activities of teachers at gifted high schools in Hanoi according to the competency approach. According to the competency approach identified above, the questionnaire was built according to 7 contents of managing teaching activities of teachers of a high school for the gifted in Hanoi. Respondents rate the items asked in 5 levels: level 1 (poor), level 2 (below average), level 3 (average), level 4 (good), level 5 (excellent).

Index of evaluation levels: Level 1: Not response; Level 2: Partly in response; Level 3: Basic response; Level 4: Responses most, but not wholly; Level 5: Fully responsive.

The survey data were entered and processed using SPSS statistical software. The score range of the scale used in the analysis calculated according to the formula combining the mean and mean of the whole scale, from which there are five levels as follows:

- Excellent level: Mean from 4.21 to 5.0

- Good level: Mean from 3.41 to 4.20

- Average level: Mean from 2.61 to 3.40

- Below average level: Mean from 1.81 to 2.60

- Poor level: Mean from 1.0 to 1.80 .

\section{THE CURRENT SITUATION OF MANAGING TEACHING ACTIVITIES OF TEACHERS AT GIFTED HIGH SCHOOLS IN HANOI ACCORDING TO COMPETENCY APPROACH}

\subsection{The current situation of teachers' teaching objectives management}

* General assessment of the current situation of teachers' goal management of teaching activities

The results of the study on the general situation of the teachers' goal management of teaching activities at gifted high schools according to competency approach reflected in the following data table:

Table 1: Collect the assessment of the current situation of teachers' teaching goal management.

\begin{tabular}{|c|c|c|c|c|}
\hline Number & Content & Mean & $\begin{array}{c}\text { Std. } \\
\text { Deviation }\end{array}$ & Rank \\
\hline 1 & $\begin{array}{l}\text { Develop a plan to implement teaching goals for gifted high school students } \\
\text { according to competency approach. }\end{array}$ & 3,83 & 0,75 & 2 \\
\hline 2 & $\begin{array}{l}\text { Direct and unify the implementation of teaching objectives towards forming } \\
\text { general and specific competencies and gifted development for students in } \\
\text { specialized classes. }\end{array}$ & 3,61 & 0,86 & 4 \\
\hline 3 & $\begin{array}{l}\text { Organize for teachers to design teaching goals towards forming general and } \\
\text { specific competencies for students in each chapter and each lesson with } \\
\text { advanced and in-depth requirements for students in specialized classes. }\end{array}$ & 3,60 & 0,82 & 5 \\
\hline 4 & $\begin{array}{l}\text { Direct and organize teachers to achieve the goals of each subject, each chapter, } \\
\text { each lesson, and each lesson with advanced and intensive requirements for } \\
\text { students in specialized classes. }\end{array}$ & 4,23 & 078 & 1 \\
\hline 5 & $\begin{array}{l}\text { Examine and evaluate teachers' performance of teaching goals for gifted high } \\
\text { school students according to competency approach }\end{array}$ & 3,67 & 0,99 & 3 \\
\hline
\end{tabular}




\section{International Journal of Current Science Research and Review}

ISSN: 2581-8341

Volume 04 Issue 10 October 2021

DOI: 10.47191/ijesrr/V4-i10-03, Impact Factor: 5.825

IJCSRR @ 2021

www.ijcsrr.org

\begin{tabular}{|l|l|c|c|c|}
\hline 6 & $\begin{array}{l}\text { Direct the adjustment of teaching content for gifted high school students } \\
\text { according to the competency approach according to the set goals }\end{array}$ & 3,54 & 0,94 & 6 \\
\hline & Mean & $\mathbf{3 , 7 5}$ & & \\
\hline
\end{tabular}

The general situation of the management of teaching goals of the teachers at the gifted high school is assessed at a reasonable level with the mean $=3.75$. This shows that the management of teaching objectives of teachers at gifted high schools has been assessed by two groups of surveyed subjects, namely administrators, teachers and students, as having fully responded to the requirements about the management of teaching objectives in gifted high schools.

However, the management of teachers' teaching goals is still limited. This reflects in the most underrated aspect: "Directing the adjustment of teaching content for gifted high school students according to the competency approach according to the set objectives" with mean $=3.54$ and "Organizing for teachers to design teaching objectives towards forming general and specific competencies for students in each chapter, each lesson with advanced and in-depth requirements for students in specialized classes" with a mean $=3.60$.

In the management of the achievement of teaching goals, the most appreciated aspect is "Directing and organizing teachers to achieve the goals of each subject, each chapter, each lesson and each lesson with advanced requirements. and intensive for students in specialized classes" with mean $=4.23$, excellent level. It means the direction and organization for teachers to implement the goals of each subject, each chapter, each lesson, and each lesson with advanced and intensive requirements for students in specialized classes have fully responded to the management requirements of each subject, each chapter, each lesson and each lesson. The second aspect evaluates "Developing a plan to implement teaching goals for gifted high school students according to competency approach" with an mean $=3.83$, good level, close to an excellent level.

* For teacher's assessment: The mean of teacher's assessment is 3.78 ; std $=0.33$ shows that teachers assess the situation of managing teaching goals of teachers at gifted high schools at a good level. The opinions of the teachers were entirely consistent when the mean $=0.33<0.5$. However, there is a statistically significant difference between these aspects of managing content. There are five aspects evaluated with good performance, and one aspect evaluated with average performance. As follows:

The aspects most appreciated by teachers are "Directing and organizing teachers to achieve the goals of each subject, each chapter, each lesson and each lesson with advanced and intensive requirements for students in the specialized classes" with mean $=$ 4.12 and "Directing uniformly implementing teaching goals towards forming general capacity, specific capacity and developing giftedness for students in specialized classes" with mean $=4.07$.

According to teachers' assessment, one aspect of this management content has an average level of performance: "Testing and evaluating teachers' performance of teaching goals for gifted high school students according to the approach capacity", mean = 3.19. It means the activity of testing and evaluating teachers' performance of teaching goals for gifted high school students meets the requirements of teaching teachers in specialized high schools. This is the most significant limitation of this management content.

* For teacher's assessment: With general mean $=3.72 ; \mathrm{std}=0.36$ shows that administrators assess the actual situation of teaching goals of teachers at gifted high schools at a good level. Thus, the management staff of 03 specialized high schools were surveyed and assessed that the management of the teachers' teaching goals fully met the school's requirements. However, there is a statistically significant difference between these aspects of managing content. There are four aspects assessed with good performance, and two aspects evaluated with average performance. Specifically as follows: Two aspects of this management content have an average level of performance, namely: "Directing the implementation of teaching objectives towards the formation of general and specific competencies and develop giftedness for students in specialized classes", mean $=3.15$; "Organizing teachers to design teaching goals towards forming general and specific competencies for students in each chapter, each lesson with advanced and in-depth requirements for students in specialized classes", mean $=3.35$.

According to administrators, these two concepts meet the school's requirements and are the two most limited manifestations of this management content.

\subsection{The reality of content management of teachers' teaching activities}

* General assessment of the current situation of teaching content management of teachers

The general research results on the current situation of teaching content management of gifted high school teachers according 


\section{International Journal of Current Science Research and Review}

ISSN: 2581-8341

Volume 04 Issue 10 October 2021

DOI: 10.47191/ijcsrr/V4-i10-03, Impact Factor: 5.825

IJCSRR @ 2021

www.ijesrr.org

to competency approach reflected in the following data table:

Table 2: Overall assessment of the current situation of teacher's teaching content management

\begin{tabular}{|c|c|c|c|c|}
\hline Number & Content & Mean & $\begin{array}{c}\text { Std. } \\
\text { Deviation }\end{array}$ & Rank \\
\hline 1 & $\begin{array}{l}\text { Direct teachers to strictly comply with the requirements of the teaching } \\
\text { program at the gifted high school according to competency approach. }\end{array}$ & 3,92 & 0,78 & 4 \\
\hline 2 & $\begin{array}{l}\text { Direct and organize for teachers to identify critical, essential, extended, } \\
\text { and advanced knowledge blocks for students in specialized classes in } \\
\text { each subject, chapter, or lesson. }\end{array}$ & 3,62 & 0,85 & 5 \\
\hline 3 & $\begin{array}{l}\text { Direct and organize for teachers to design teaching content closely } \\
\text { following the formation-oriented competencies for students in gifted } \\
\text { high schools. }\end{array}$ & 4,04 & 0,67 & 1 \\
\hline 4 & $\begin{array}{l}\text { Organize for teachers to implement competency-based teaching } \\
\text { content for gifted high school students. }\end{array}$ & 4,03 & 0,81 & 2 \\
\hline 5 & $\begin{array}{l}\text { Check and evaluate the implementation of teaching content and } \\
\text { programs of teachers of gifted high schools. }\end{array}$ & 3,93 & 0,85 & 3 \\
\hline & Mean & 3,90 & $\mathbf{0 , 7 8}$ & \\
\hline
\end{tabular}

The research results shown in the above table show that the level of performance management of teachers' teaching contents of gifted high schools according to competency approach is assessed by administrators and teachers of the surveyed schools achieved a good level, with mean $=3.90$. This means that the teachers' teaching content management has been met quite well and implemented quite well.

All aspects considered under this management content are assessed to have a good level of performance (mean from 3.62 to 4.04). Thus, the implementation of teaching content management by teachers of gifted high schools according to competency approach is strictly implemented, by regulations and achieved a good level of performance in all aspects such as teachers strictly comply with the requirements of teaching programs at specialized high schools according to competence approach; Directing and organizing teachers to identify the core, fundamental, extended and advanced knowledge blocks for students in gifted classes in each subject, chapter, or lesson; Directing and organizing for teachers to design teaching content following the oriented competencies formed for students in gifted high schools; Organize for teachers to deploy teaching content according to competency approach for students of gifted high schools; Check and evaluate the implementation of the content and curriculum of the teachers of the specialized high schools.

Of the five aspects, the management aspect, "Directing and organizing for teachers to design teaching content in line with the orientation of forming competencies for students in gifted high schools," is the most appreciated with an mean $=4$, 04. The second-ranked aspect is "Organizing teachers to deploy teaching content according to competency-based approach for students in gifted high schools" with mean $=4.03$.

The most underrated aspects are "Directing and organizing for teachers to identify the core, basic, extended and advanced knowledge blocks for students in specialized classes in each subject, chapter, and lesson" and "Directing teachers to strictly comply with the requirements of the teaching program at gifted high schools according to competency approach."

* Evaluation of teachers: The group of teachers of three gifted high schools was asked to rate the management of teacher's teaching content at specialized high schools according to competency approach at a good level $($ mean $=3.92)$. Thus, the teachers think teaching content management of teachers at gifted high schools according to competency approach has been done quite well.

The teachers highly appreciated the aspects "Directing and organizing for teachers to design teaching content following the oriented competencies forming for gifted high school students," mean $=4.06$. The second aspect, "Organizing teachers to deploy teaching content according to competency-based approach for gifted high school students," mean = 4.05.

The most limited point in the management of teacher's teaching content, according to the teacher's own assessment, is "Directing and organizing for teachers to identify the central, basic, extended and advanced knowledge blocks for gifted high school 


\section{International Journal of Current Science Research and Review}

ISSN: 2581-8341

Volume 04 Issue 10 October 2021

DOI: 10.47191/ijcsrr/V4-i10-03, Impact Factor: 5.825

IJCSRR @ 2021

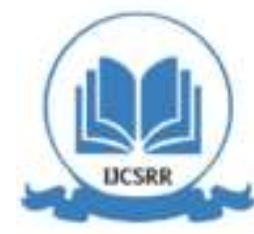

Www.ijcsrr.org

classes in each subject, chapter, or lesson," mean $=3.64$, the level of performance is good, close to the average level of performance. Therefore, to more effectively manage the teaching content of specialized high school teachers according to the competency approach, the principals of the studied schools need to find more appropriate and effective management measures.

*Assessment of administrators: The level of performance management of teaching content by teachers of gifted high schools according to competency approach was assessed as good by the managers of the surveyed gifted high schools, with mean = 4.20; mean $=0.24$. However, there is a statistically significant difference between these aspects of managing content. There are four aspects evaluated with good performance, and one aspect considered with average performance. As follows:

Aspects that evaluated with a good level of performance are: "Directing and organizing teachers to design teaching content following the oriented competencies forming for students in gifted high schools"; "Testing and evaluating the implementation of teaching contents and programs by teachers of specialized high schools"; "Organize teachers to deploy teaching content according to competency approach for gifted high school students"; "Directing teachers to strictly comply with the requirements of the teaching program at specialized high schools according to competency approach" with mean of 3.60 to 4.05 . The most appreciated aspect is "Directing and organizing for teachers to design teaching content following the oriented competencies forming for students in gifted high schools," with mean $=4.05$.

There is one aspect of management content that is rated lowest and at an average level of performance: "Directing and organizing teachers to identify the core, basic, extended and advanced knowledge blocks for teachers. students in specialized classes in each subject, chapter, or lesson" with mean of 3.40. This assessment coincides with the teacher's assessment.

\subsection{The current status of teachers' implementation of management using teaching methods}

* General assessment of the management situation using teaching methods of teachers

The results of the research on the current situation of management using teaching methods of teachers at gifted high schools according to competency approach reflected in the following data table:

Table 3: Evaluation of the current situation of teachers using teaching methods

\begin{tabular}{|c|c|c|c|c|}
\hline Number & Content & Mean & $\begin{array}{c}\text { Std. } \\
\text { Deviation }\end{array}$ & Rank \\
\hline 1 & $\begin{array}{l}\text { Develop a plan to use teaching methods for gifted high school } \\
\text { students according to the competency approach }\end{array}$ & 3,76 & 0,73 & 5 \\
\hline 2 & $\begin{array}{l}\text { Direct and organize teachers to use teaching methods for } \\
\text { gifted high school students according to the competency } \\
\text { approach }\end{array}$ & 3,97 & 0,95 & 2 \\
\hline 3 & $\begin{array}{l}\text { Direct teachers in teaching methods for gifted high school } \\
\text { students according to competency approach suitable to the } \\
\text { content, form, and learning capacity of gifted high school } \\
\text { students. }\end{array}$ & 4,02 & 0,78 & 1 \\
\hline 4 & $\begin{array}{l}\text { Examine and evaluate the use of teaching methods for gifted } \\
\text { high school students according to the competency approach }\end{array}$ & 3,86 & 0,76 & 3 \\
\hline \multirow[t]{2}{*}{5} & $\begin{array}{l}\text { Direct the adjustment of teaching methods for gifted high } \\
\text { school students according to the ability to approach the set } \\
\text { goals }\end{array}$ & 3,85 & 0,79 & 4 \\
\hline & Mean & 3,88 & $\mathbf{0 , 8 0}$ & \\
\hline
\end{tabular}

The survey results on the current situation of management using teaching methods of teachers of gifted high schools were assessed by the administrators and teachers of gifted high schools as good with an mean of 3.88 and the mean of 3.88 , and the mean is 0.80 . These results mean that the school managed to implement the teacher's teaching method to a reasonable extent. 


\section{International Journal of Current Science Research and Review}

ISSN: 2581-8341

Volume 04 Issue 10 October 2021

DOI: 10.47191/ijcsrr/V4-i10-03, Impact Factor: 5.825

Among the five aspects considered in this management content, the most appreciated aspect is "Direct teachers in teaching methods for gifted high school students according to the competency-based approach appropriate to the content, form, and learning capacity of students in gifted schools", with mean of 4.02

The two most underrated aspects are "Develop a plan to use teaching methods for gifted high school students according to competency-based approach" with mean of 3.76 and "Direct the adjustment of teaching methods for gifted high school students according to the ability to approach the set goals" with mean of 3.85. These average scores show that the management and development of plans to use teaching methods for gifted high school students according to the school's capacity approach only basically meets the requirements of the school and is still limited.

*Teacher's assessment: The group of teachers of 3 gifted high schools were asked to evaluate the management and use of teaching methods of gifted high school teachers according to the competency-based approach at a good level (mean is 3.90; mean is 0.36 ). Thus, the teachers also evaluated the school's management of the teacher's use of teaching methods relatively well, fully meeting the requirements for managing this issue.

The teachers highly appreciated the aspects of "Direct teachers in teaching methods for gifted high school students according to competency approach suitable to the content, form, and learning capacity of gifted high school students.", with an mean of 4.02. The most limited point in the management of teaching content of teachers according to the teacher's assessment is "Develop a plan to use teaching methods for gifted high school students according to the competency approach", with the mean is 3.76, the level of performance is good, close to the average level of performance. Therefore, to more effectively manage the teaching content of teachers of specialized high schools according to the competency-based approach, the principals of the studied schools need to find more appropriate and effective management measures in this aspect.

*Evaluation of administrators: The level of implementation of the teaching method management of gifted high school teachers according to the competency-based approach was assessed by administrators of the surveyed schools as good, with an mean is 3.86; mean is 0.42 .

All five aspects of this management content are assessed as having a good level of performance (mean from 3.70 to 4.05 ). Thus, the management of teaching methods of teachers of gifted high schools according to competency-based approach is strictly implemented, by regulations and achieved a good level of performance in all aspects such as: Develop a plan to use teaching methods for gifted high school students according to competency-based approach; Direct and organize teachers to use teaching methods for gifted high school students according to the competency-based approach; Direct teachers in teaching methods for gifted high school students according to competency approach suitable to the content, form, and learning capacity of gifted high school students; Examine and evaluate the use of teaching methods for gifted high school students according to the competency-based approach; Direct the adjustment of teaching methods for gifted high school students according to the ability to approach the set goals.

\subsection{The current status of teachers' management of teaching and learning forms}

* General assessment of the status of teachers' management of teaching forms

The study results on the current status of teachers' teaching forms management of gifted high schools according to the competency-based approach of two groups of survey subjects (administrators, teachers) are reflected in the following data table:

Table 4: Assessment of the current status of teachers' teaching method management

\begin{tabular}{|c|c|c|c|c|}
\hline Number & Content & Mean & $\begin{array}{c}\text { Std. } \\
\text { Deviation }\end{array}$ & Rank \\
\hline 1 & $\begin{array}{l}\text { Develop a plan to use teaching forms for gifted high school } \\
\text { students according to a competency-based approach suitable to } \\
\text { the characteristics of the school and the characteristics of gifted } \\
\text { high school students. }\end{array}$ & 3,57 & 0,76 & 4 \\
\hline 2 & $\begin{array}{l}\text { Deploy and direct the use of teaching forms for gifted high school } \\
\text { students according to a competency-based approach suitable to } \\
\text { the characteristics of the school and the characteristics of gifted } \\
\text { high school students }\end{array}$ & 3,76 & 0,82 & 3 \\
\hline
\end{tabular}




\section{International Journal of Current Science Research and Review}

ISSN: 2581-8341

Volume 04 Issue 10 October 2021

DOI: 10.47191/ijcsrr/V4-i10-03, Impact Factor: 5.825

IJCSRR @ 2021

www.ijjesrr.org

\begin{tabular}{|l|l|c|c|c|}
\hline 3 & $\begin{array}{l}\text { Examine and evaluate the use of teaching forms for gifted high } \\
\text { school students according to a competency-based approach }\end{array}$ & 3,80 & 0,91 & 2 \\
\hline 4 & $\begin{array}{l}\text { Direct the adjustment of teaching forms for gifted high school } \\
\text { students according to a competency-based approach to suit the } \\
\text { needs and conditions of the school and students. }\end{array}$ & 4,14 & 0,76 & 1 \\
\hline & General average score & $\mathbf{3 , 8 1}$ & $\mathbf{0 , 8 3}$ & \\
\hline
\end{tabular}

The current situation of the teaching method management of gifted high school teachers according to the competencybased approach is assessed as good with an mean of 3.76 and mean of 0.83 . This means that the two groups evaluating the management of teachers' teaching forms at gifted high schools according to the competency-based approach have performed relatively well, fully meeting the requirements for teaching forms management. However, there are still certain limitations.

The most significant limitation of this management content is reflected in the following aspects: "Develop a plan to use teaching forms for gifted high school students according to the competency-based approach suitable to the characteristics of the school, characteristics of gifted high school students". This is the aspect with the lowest average rating (3.59) in this management content of the school.

However, all four aspects of this content are good, in which the most appreciated aspect is "Direct the adjustment of teaching forms for gifted high school students according to the competency-based approach to suit the needs and conditions of schools and students" with an mean of 4.14; followed by "Examine and evaluate the use of teaching forms for gifted high school students according to competency-based approach" with an mean of 3.80 .

*Teacher's assessment: with an mean of 3.86, the current status of the management of teaching forms of gifted high school teachers according to the competency-based approach is assessed by teachers of three gifted high schools at a good level of performance. This result shows that the teachers of the three surveyed gifted high schools to evaluate the current situation of teachers' teaching forms management are focused and implemented quite well.

The most appreciated aspect is "Direct the adjustment of teaching forms for gifted high school students according to competency-based approach to suit the needs and conditions of schools and students" with an mean of 4, 13. The most underrated aspect is "Develop a plan to use teaching forms for gifted high school students according to a competency-based approach suitable to the characteristics of the school and the characteristics of gifted high school students." with an mean of 3.59, which is quite good, close to the average.

*Evaluation of the administrators: The level of managing the implementation of teachers' teaching forms at gifted high school according to the competency-based approach was assessed by the school administration as good with the mean of 3.78; the mean is 0.44 . All four aspects of this management content are assessed at the good performance (mean from 3.55 to 4.15 ).

\subsection{Current situation of management of facilities and equipment for teaching and learning activities of teachers}

*General assessment of the current situation of teachers' management of facilities and teaching equipment

The study results on the current situation of management and use of facilities and teaching equipment by gifted high school teachers are reflected in the following data table:

Table 5: Assessment of the current situation of management and use of facilities, means, and teaching equipment

\begin{tabular}{|c|l|c|c|c|}
\hline Number & Content & Mean & $\begin{array}{c}\text { Std. } \\
\text { Deviation }\end{array}$ & \begin{tabular}{c} 
Rank \\
\hline 1
\end{tabular} \\
\hline $\begin{array}{l}\text { Develop a plan to invest and use material and technical facilities } \\
\text { in service of teaching for gifted high school students according to } \\
\text { competency-based approach }\end{array}$ & 3,82 & 0,93 & 3 \\
\hline 2 & $\begin{array}{l}\text { Deploy and direct the investment and use of material and technical } \\
\text { facilities in service of teaching for gifted high school students } \\
\text { according to competency-based approach }\end{array}$ & 3,82 & 0,75 & 4 \\
\hline
\end{tabular}




\section{International Journal of Current Science Research and Review}

ISSN: 2581-8341

Volume 04 Issue 10 October 2021

DOI: 10.47191/ijesrr/V4-i10-03, Impact Factor: 5.825

IJCSRR @ 2021

www.ijesrr.org

\begin{tabular}{|c|l|c|c|c|}
\hline 3 & $\begin{array}{l}\text { Direct and foster the teachers and full-time staff to use material } \\
\text { and technical facilities in service of teaching for gifted high school } \\
\text { students according to competency-based approach }\end{array}$ & 3,69 & 0,86 & 4 \\
\hline 4 & $\begin{array}{l}\text { Direct and organize the mobilization of social resources to } \\
\text { strengthen material and technical facilities in service of teaching } \\
\text { activities for gifted high school students according to competency- } \\
\text { based approach }\end{array}$ & 3,90 & 0,82 & 2 \\
\hline 5 & $\begin{array}{l}\text { Examine and evaluate the use of material and technical facilities } \\
\text { in service of teaching for gifted high school students according to } \\
\text { competency-based approach }\end{array}$ & 3,52 & 0,88 & 5 \\
\hline 6 & $\begin{array}{l}\text { Direct the adjustment of investment and use of material and } \\
\text { technical facilities in service of teaching for gifted high school } \\
\text { students according to competency-based approach }\end{array}$ & 4,04 & 0,81 & 1 \\
\hline & Mean & $\mathbf{3 , 7 9}$ & $\mathbf{0 , 8 4}$ & \\
\hline
\end{tabular}

The current situation of management and use of facilities and teaching equipment of gifted high schools teachers are evaluated at a good level, with an mean of 3.79. This shows that the three surveyed gifted high schools have managed the teachers relatively in using facilities, means, and equipment to serve teaching activities at gifted high schools. Facilities, means, and equipment for teaching activities are some of the most crucial factors in ensuring that teaching activities are carried out according to the set plan and done with good quality.

However, this management content still has limitations. These are the aspects of "Examine and evaluate the use of material and technical facilities in service of teaching for gifted high school students according to competency-based approach". This is the lowest rated management aspect of the surveyed aspects of this content, with an mean of 3.52.

The most appreciated aspect is "Direct the adjustment of investment and use of material and technical facilities in service of teaching for gifted high school students according to competency-based approach" with an mean of 4.04 and "Direct and organize the mobilization of social resources to strengthen material and technical facilities in service of teaching activities for gifted high school students according to competency-based approach

" with an mean of 3.90 .

\subsection{The current situation of managing the examination and evaluation of teachers' teaching activities}

*General assessment of the current situation of managing the examination and evaluation of teachers' teaching activities

The study results on the current situation of managing the examination and evaluation of teachers' teaching activities are reflected in the following data table:

Table 6: Assessment of the current situation of managing the examination and evaluation of teachers' teaching activities

\begin{tabular}{|c|c|c|c|c|}
\hline Number & Content & Mean & $\begin{array}{c}\text { Std. } \\
\text { Deviation }\end{array}$ & Rank \\
\hline 1 & $\begin{array}{l}\text { Develop a plan to examine and evaluate teachers' teaching } \\
\text { activities at gifted high school according to competency-based } \\
\text { approach }\end{array}$ & 3,81 & 0,81 & 5 \\
\hline 2 & $\begin{array}{l}\text { Clearly define the purposes and requirements of testing and } \\
\text { evaluating teachers' teaching activities at gifted high school } \\
\text { according to competency-based approach }\end{array}$ & 3,93 & 0,81 & 1 \\
\hline 3 & $\begin{array}{l}\text { Develop the standards and evaluation criteria for teachers' teaching } \\
\text { activities at gifted high schools according to competency-based } \\
\text { approach }\end{array}$ & 3,70 & 0,86 & 6 \\
\hline
\end{tabular}




\section{International Journal of Current Science Research and Review}

ISSN: 2581-8341

Volume 04 Issue 10 October 2021

DOI: 10.47191/ijcsrr/V4-i10-03, Impact Factor: 5.825

IJCSRR @ 2021

www.ijjcsrr.org

\begin{tabular}{|l|l|c|c|c|}
\hline 4 & $\begin{array}{l}\text { Prepare a force to examine and evaluate teachers' teaching } \\
\text { activities at gifted high school according to competency-based } \\
\text { approach }\end{array}$ & 3,91 & 0,89 & 3 \\
\hline 5 & $\begin{array}{l}\text { Prepare a plan to examine and evaluate teachers' teaching } \\
\text { activities at gifted high school according to competency-based } \\
\text { approach }\end{array}$ & 3,93 & 0,83 & 1 \\
\hline 6 & $\begin{array}{l}\text { Evaluate, learn from experience, and make timely adjustments } \\
\text { after testing teachers' teaching activities at gifted high school } \\
\text { according to competency-based approach }\end{array}$ & 3,82 & 0,75 & 4 \\
\hline & Mean & $\mathbf{3 , 8 5}$ & $\mathbf{0 , 8 3}$ & \\
\hline
\end{tabular}

The managers and teachers of three gifted high schools were surveyed to evaluate the situation of management of examination and evaluation of teachers' teaching activities at gifted high schools at a good level with an mean of 3,85 , and the mean is 0.83 . That is, according to the assessment, the management of examination and evaluation of these three gifted high schools has fully met the requirements for examining and evaluating the teaching activities.

However, at a good level, it shows that there are still certain limitations. The most underrated aspect is "Develop the standards and evaluation criteria for teachers' teaching activities at gifted high schools according to competency-based approach". Other aspects of performance management are not significantly different and are all at a good level. The most appreciated aspect is " Prepare a plan to examine and evaluate the teachers' teaching activities at gifted high school according to competency-based approach " with an mean of 3.93 .

The teachers surveyed to assess the current situation of management of examination and evaluation of teachers' teaching activities at gifted high schools was good with an mean of 3.83. Thus, according to the surveyed teachers, the school has examined and evaluated teachers' teaching and learning activities quite well. Therefore, the quality of teaching in gifted high schools is always guaranteed. The most appreciated aspect is "Clearly define the purposes and requirements of testing and evaluating teachers' teaching activities at gifted high school according to competency-based approach" with an mean of 3.93. The most underrated aspect is "Develop a plan to examine and evaluate teachers' teaching activities at gifted high school according to competency-based approach" with an mean of 3.73 .

The administrators of three gifted high schools were surveyed to assess the current management situation of examining and evaluating teachers' teaching activities at a good level with an mean of 3.87 and a mean of 0.31 . That is, the management of the examination and evaluation of these three gifted high schools has fully met the requirements.

However, it shows that there are still certain limitations. The most underrated aspect is "Develop a plan to examine and evaluate teachers' teaching activities at gifted high school according to competency-based approach". Other aspects are not significantly different and all at good level.

3.7. General assessment of the current situation of managing teachers' teaching activities at gifted high schools according to competency-based approach

General assessment of the current situation of managing teachers' teaching activities at gifted high school is reflected in the following data table:

Table 7: General assessment of the current situation of managing teachers' teaching activities

\begin{tabular}{|c|c|c|c|c|c|}
\hline Number & Managing content & $\begin{array}{l}\text { Administrators } \\
\quad(\text { mean })\end{array}$ & $\begin{array}{l}\text { Teachers } \\
\text { (mean) }\end{array}$ & $\begin{array}{l}\text { Overall } \\
\text { (mean) }\end{array}$ & Rank \\
\hline 1 & $\begin{array}{l}\text { Current situation of managing the performance of } \\
\text { teachers' teaching goals }\end{array}$ & 3,72 & 3,78 & 3,75 & 6 \\
\hline 2 & $\begin{array}{l}\text { Current situation of managing the implementation } \\
\text { of teacher's teaching contents }\end{array}$ & 4,20 & 3,89 & 3,90 & 1 \\
\hline
\end{tabular}




\section{International Journal of Current Science Research and Review}

ISSN: 2581-8341

Volume 04 Issue 10 October 2021

DOI: 10.47191/ijcsrr/V4-i10-03, Impact Factor: 5.825

IJCSRR @ 2021

www.ijjesrr.org

\begin{tabular}{|c|l|c|c|c|c|}
\hline 3 & $\begin{array}{l}\text { Current situation of managing the implementation } \\
\text { of teacher's teaching methods }\end{array}$ & 3,86 & 3,90 & 3,88 & 2 \\
\hline 4 & $\begin{array}{l}\text { Current situation of managing the implementation } \\
\text { of teacher's teaching forms }\end{array}$ & 3,77 & 3,86 & 3,81 & 4 \\
\hline 5 & $\begin{array}{l}\text { Current situation of managing the use of facilities, } \\
\text { means, and teaching equipment of teachers }\end{array}$ & 3,78 & 3,81 & 3,79 & 5 \\
\hline 6 & $\begin{array}{l}\text { Current situation of managing the examination } \\
\text { and evaluation of teacher's teaching results }\end{array}$ & 3,87 & 3,83 & 3,85 & 3 \\
\hline & Mean & $\mathbf{3 , 8 6}$ & $\mathbf{3 , 8 4}$ & $\mathbf{3 , 8 5}$ & \\
\hline
\end{tabular}

With 3.85, the mean of the whole scale of managing teachers' teaching activities at gifted high schools according to competency-based approach is good. The study results show that the current situation of managing teachers' teaching activities at gifted high schools surveyed at three gifted schools is quite well done, fully meet the requirements of managing teachers' teaching activities and meet the requirements of high-quality student training of today's gifted high schools.

\section{CONCLUSION}

Thus, the principals and administrators of the three gifted high schools have well-managed teachers' teaching activities according to the competency-based approach. This management activity is done quite well in terms of teachers' objectives, content, form, and teaching methods. Besides, the management of facilities for teachers' teaching activities and examination and evaluation of the teaching results of teachers at gifted high schools according to competency-based approach is good as well.

The management contents have no significant difference in average score. This shows that the content is done relatively evenly. The most appreciated aspects are "Current situation of managing the implementation of teacher's teaching contents", "Current situation of managing the implementation of teacher's teaching methods", and "Current situation of managing the examination and evaluation of teacher's teaching results". The lower-rated content is "Current situation of managing the performance of teachers' teaching goals".

A needed-explaining problem is why the content and management of the teachers' teaching activities of the three gifted high schools surveyed according to the competency-based approach are rated at a reasonable Level - the Level of performing pretty well the management contents and approximately meet all the requirements? Through practical surveys and in-depth interviews with administrators and teachers of the three surveyed gifted high schools, the problem is explained as follows:

- Firstly, the three surveyed gifted high schools are: 1) Hanoi - Amsterdam High School for The Gifted; 2) Foreign Language Specialized School (a part of University of Language and International Studies - VNU), 3) The High School for Gifted Students, Hanoi National University of Education. These are three of the top gifted high schools and are famous for their training quality and reputation today. Therefore, the school administrators, departments, and department heads have professional qualifications and good management capacity.

- Secondly, as the top three specialized high schools in the country, the teachers are carefully selected, have high professional qualifications and pedagogical skills to meet the requirements of intensive and high-quality training for students who are high-quality human resources for the country in the future.

- Thirdly, the students of these three gifted high schools have very high-quality input, so they have an excellent learning mindset, have good foreign language skills, good computer skills, and good study skills. These are necessary favorable conditions for teachers' teaching activities according to competency-based approach. It greatly supports the teaching activities of teachers according to the competency-based approach with good efficiency.

\section{REFERENCES}

1. The Prime Minister (2010). Decision no. 959/QD-TTg dated June 24, 2010, approving the scheme on development of the system of specialized upper secondary schools in the 2010-2020 period.

2. Vuong, T.B.T. (2015), Doi moi phuong phap day hoc theo dinh huong phat trien nang luc nguoi hoc [Innovating teaching methods towards competency-based teaching]. Journal of Educational Management, 4, 158-162. 


\section{International Journal of Current Science Research and Review}

ISSN: 2581-8341

Volume 04 Issue 10 October 2021

DOI: 10.47191/ijesrr/V4-i10-03, Impact Factor: 5.825

3. Vietnam National Congress (2005). Law of Education (No. 38/2005/QH11 dated June 14, 2005).

4. Trinh, N.T. (2017). Thuc trang quan ly day hoc mon chuyen o truong trung hoc pho thong chuyen theo dam bao chat luong [Managing teaching of specialized subjects in specialized high schools towards quality management]. Journal of Education, special issue, vol 3 August 2017.

5. UNESCO (1998), Developing Instructional Modules for Teacher Education, Regional office for Education in Asia, Bangkok

Cite this Article: Nguyen Thi Nga (2021). Managing Competency-Based Teaching of Teachers at Specialized High Schools in Hanoi. International Journal of Current Science Research and Review, 4(10), 1203-1213 